\title{
The Implementation of Think Pair Share Assisted with Pop Up Media Increases Students' Outcomes
}

\author{
*Yenni Oktaviani1 ${ }^{1}$, Erik Aditia Ismaya ${ }^{2}$, Eko Widianto ${ }^{3}$ \\ 1.2,3 Program Studi Pendidikan Guru Sekolah Dasar, Universitas Muria Kudus, Kudus, Indonesia
}

\author{
A R T I C L E I N F O \\ Article history: \\ 1 Mei 2020 Received in \\ revised form \\ 11 Juni 2020 \\ Accepted 10 Juli 2020 \\ Available online 25 Agustus \\ 2020 \\ Kata Kunci: \\ think pair share, hasil \\ belajar \\ Keywords: \\ think pair share, learning \\ outcomes
}

\begin{abstract}
A B S T R A K
Dalam pembelajaran saat ini, guru masih menggunakan metode ceramah dan jarang menggunakan media sebagai penunjang pembelajaran sehingga siswa merasa bosan dan kurang antusias dalam mengikuti kegiatan pembelajaran mengakibatkan rendahnya hasil belajar siswa. Penelitian ini bertujuan untuk menganalisis peningkatan hasil belajar siswa ranah pengetahuan dan keterampilan menggunakan model pembelajaran think pair share berbantuan media pop up pada siswa kelas $\mathrm{V}$. Jenis penelitian ini yakni penelitian tindakan kelas. Penelitian ini terdiri dari 4 tahapan yakni perencanaan, tindakan, observasi, dan refleksi. Subjek penelitian yakni siswa kelas $V$ dengan jumlah 23 siswa. Teknik pengumpulan data dalam penelitian ini yakni tes dan non tes. Teknik analisis datanya menggunakan teknik analisis data kuantitatif dan kualitatif. Hasil penelitian ini menunjukkan bahwa hasil belajar siswa ranah pengetahuan muatan IPS pada siklus I
\end{abstract} memperoleh nilai rata-rata 69 dan muatan Bahasa Indonesia memperoleh nilai rata-rata 70 sedangkan pada siklus II muatan IPS memperoleh nilai rata-rata 79 dan muatan Bahasa Indonesia memperoleh nilai rata-rata 80 . Hasil belajar ranah keterampilan pada siklus I memperoleh nilai ratarata 66 dengan kategori perlu bimbingan sedangkan pada siklus II memperoleh nilai rata-rata 78 dengan kategori cukup. Berdasarkan hasil penelitian dapat disimpulkan bahwa dengan menerapkan model pembelajaran think pair share berbantuan media pop up dapat meningkatkan hasil belajar pada siswa kelas V.

\section{A B S T R A C T}

In current learning, teachers still use the lecture method and rarely use media to support learning so that students feel bored and less enthusiastic about participating in learning activities resulting in low student learning outcomes. This study aims to analyze the improvement of student learning outcomes in the realm of knowledge and skills using the think pair share learning model assisted by pop-up media in class $\mathrm{V}$. This type of research is classroom action research. This study consisted of 4 stages, namely planning, acting, observing, and reflecting. The research subjects were 23 students in grade V. Data collection techniques in this study were test and non-test. The data analysis technique used quantitative and qualitative data analysis techniques. The results of this study indicate that the learning outcomes of students in the domain of social science content knowledge in the first cycle obtained an average value of 69 and the Indonesian language content obtained an average value of 70 while in the second cycle the social studies content obtained an average value of 79 and the Indonesian language content obtained an average value. -averaged 80 . The results of learning skills in the first cycle obtained an average score of 66 in the category of needing guidance while in the second cycle an average score of 78 was in the sufficient category. Based on the research results, it can be concluded that applying the think pair share learning model assisted by pop up media can improve learning outcomes in class $\mathrm{V}$. 


\section{Introduction}

Education is one of the important factors in improving the quality of human resources as a determinant of the success of a nation's development. Based on Law No.20 of 2003 concerning the National Education System in Chapter II, Article 3 states that education has the function of developing abilities and shaping the character and civilization of a nation with dignity to educate the life of the nation, aiming to develop the potential of students to become faithful and human beings. be devoted to God Almighty, have a noble character, are healthy, knowledgeable, capable, creative, independent, become democratic and responsible citizens.

Education cannot be separated from learning activities. The learning process is said to be effective if the implementation of learning activities at each level and type of education has guidelines that must be adhered to, adhered to, and implemented which is called the curriculum (Ardianti, et al 2018). The learning process is said to be successful if the teacher's way of carrying out learning is not teachercentered but learning that involves students actively in learning so that learning becomes more meaningful for students, but many inaccuracies have occurred in the learning process so far. The results in the field generally show that students are not actively involved in the learning process, most of the learning time is filled by the teacher through one-way communication. Conditions like this can result in the learning atmosphere to be less interactive and lead to passive and apathetic behavior in students. To overcome this, the teacher plays an important role in improving the quality of learning, one of the efforts is to provide learning tools and learning media so that the learning process will be meaningful which allows students to achieve maximum student learning outcomes. This problem is supported by the results of the observations carried out at SD 3 Bulungcangkring.

SD 3 Bulungcangkring is an educational unit in Kudus Regency, Jekulo sub-district that has implemented the 2013 curriculum. The results of interviews on October 2, 2019, with grade V SD 3 Bulungcangkring students found several problems, namely students having difficulty understanding the subject matter of social studies and Indonesian language due to too much material. and a lack of explanation from the teacher. This problem occurs because the teacher in carrying out the learning process rarely uses the media to support learning and still uses the lecture method, so students feel bored and less enthusiastic in participating in learning activities.

Based on observations on October 3, 2019, carried out in the research class, the students found several weaknesses in writing skills, namely that students could not make a good summary, this was because students could not understand the contents of the text in reading, and students also still experienced difficulties in selecting the right words in composing the correct sentence so that students feel afraid if their writing is wrong. Not only in writing skills, but students also have weaknesses in interacting with other students so that when the teacher holds group discussions, students are still individualistic in doing their assignments. If it continues to exist in students, it will affect student learning outcomes.

Based on the midterm test scores (UTS) class V SD 3 Bulungcangkring, it is known that the students' scores are still below the maximum completeness criteria (KKM) for social studies content and Indonesian language $\geq 70$. In social studies content, there are 39\% (9 out of 23 students) who have experienced complete learning while $61 \%$ (14 of 23 students) who have not experienced learning completeness, and in Indonesian language content there are 43\% (10 of 23 students) who have experienced learning completeness while 57\% (13 of 23 students) have not experienced learning completeness. Based on this, students who are less well off in social studies will become students who do not understand the conditions and circumstances of their environment. In addition to this, students who do not understand and do not understand Indonesian subjects will make it difficult to communicate and convey ideas. Both of these things in addition to affecting the value of student learning outcomes will have an impact on students' daily lives, for example, when a formal situation student is unable to speak Indonesian well, it could be misleading. The next example is when students are in a new area or environment, if students do not know the environment it will make students confused in acting and mingling. Seeing all the problems that arise, these problems need to be resolved.

Based on the above problems, one of the right solutions is in the implementation of the learning process it is necessary to apply a learning model that can improve student learning outcomes. To improve learning outcomes, researchers have the initiative to apply the think pair share a cooperative learning model with the help of pop up media. It is intended that students can take an active role in understanding learning concepts and be able to solve problems in a discussion.

The TPS learning model was chosen because according to (Hamdayama, 2014) thinks Think Pair Share (TPS) is a simple technique with big benefits. Besides, according to (Trianto, 2014), the TPS learning model is a learning model that affects student interaction patterns. Furthermore, (Huda, 2015) conveyed 
that the TPS learning model gave students time to think about answers to the questions or problems being discussed, then students solve these problems with their respective abilities then explain the results obtained in front of the class.

Based on this explanation, it can be concluded that the TPS learning model is a learning model that affects student interaction by inserting stages or learning processes such as thinking about answers, responding to, and determining solutions to problems. Learning is carried out in groups so that interaction occurs between students and students can work according to their respective abilities, this will make students complement each other.

The advantage of this learning model is that TPS can improve students' ability to remember information and a student can also learn from other students and share ideas for discussion before submitting them to the class (Ustatik, 2016). Based on the definitions according to the expert above, the advantages of the TPS learning model are, 1) increasing students' thinking power. 2) give students time to think. 3) Students become more active in thinking. 4) students have a better understanding of the concept or topic of discussion. 5) students can learn from other students. 6) each student can convey the ideas they have.

The think pair share learning model stage consists of five stages, with three main stages as characteristics, namely the preliminary stage, think, pair and share, appreciation. The explanation of each stage is as follows. 1) the preliminary stage, the beginning of learning begins with exploring perceptions as well as motivating students to be involved in learning activities. 2) the thinking stage (think individually), students are given a time limit (think time) by the teacher to think about their answers individually to the questions given. 3) the pair stage (pairing up with a peer), the teacher groups students in pairs. Then, students start working with their partners to discuss the answers to the problems that have been given by the teacher. 4) the sharing stage (sharing answers with other pairs or the whole class), students can present their answers individually or cooperatively to the class as a whole group. 5) the award stage, students receive an award in the form of values both individually and in groups.

Apart from the opinion of experts, the use of the TPS learning model is also influenced by several research results, the first is the research carried out by (S.E. \& Dra. Ni Wayan Suniasih, 2018) states that the think pair share model can give students more time to think, to respond to and help each other, so that students are expected to be able to understand the material well. Subsequent research was carried out by (Litna \& Seli, 2019) mentioned that the think pair share learning model can provide opportunities for students to suggest answers and encourage students to increase cooperation between students. Furthermore, the research was carried out by (Yustitia et al., 2018) by using the think pair share learning model can have a positive impact on the development of students' mathematical reasoning abilities. Research conducted by (Sni \& Hero, 2018) said the think pair share learning model can increase student learning activities. Finally, the research was carried out by (Tanjung \& Wardani, 2020) argues that TPS is learning that encourages students to be independent, and trains students to actively participate in class discussions. From the results of their research, they prove that applying the think pair share learning model can improve the quality of learning.

To support learning activities, researchers also use learning media, namely pop-ups. The use of this media considers the results of observations made, namely that students find it difficult to understand a concept if it is not seen directly, besides that students are also less able to remember an abstract concept. In addition, the choice of media also considers the opinion of several experts, namely, Montanaro in (Masna, 2015) explains that at first glance Pop up is similar to origami, both of these arts use paper folding techniques. Pop Up Book has its advantages over other media such as displaying a shape made by folding and having dimensions. Furthermore, (Dzuanda, 2011) states that the Pop-Up book is a book that has moving parts or has 3-dimensional elements and provides a more interesting visualization of the story, starting from the display of images that can move when the page is opened. (Muktiono, 2003), Pop Up book is a book that has an image display that can be established and forms beautiful objects and can move or give amazing effects. Pop up book media has several advantages, (Ni'mah, 2014) mentions some of the advantages of pop up as a teaching medium, including 1) pop-ups are widely used to explain complex images such as in health, mathematics, and technology; 2) books or pop up media that can be moved are effective learning strategies and make learning more effective, interactive and easy to remember; 3 ) pop ups provide learning feeds because, for students, visual illustrations can make abstract concepts clear; 4) pop-ups add new experiences for students; 5) pop-ups entertain and attract students' attention; 6) interactive pop-up passages make teaching a game-like opportunity for students to participate in it.

Furthermore, the use of pop up book media has been proven in several studies, namely, according to Oktaviarini in (Eri Karisma et al., 2020) call a pop-up book a book that can show a three-dimensional shape when the page is opened and has a motion that can be created using paper as a material for folds, rolls, shapes, or wheels. Pop up book learning media can improve student learning outcomes because in 
the pop-up book media there are 3-dimensional images and if it is open it can move, change or give an impression so that the learning material is easily understood by students. Research conducted by (Masturah et al., 2018) stated that pop up media can be used as teaching material for students because it can increase students' enthusiasm and interest in learning. Other research was conducted by (Sentarik \& Kusmariyatni, 2020) said that pop up media is made by giving surprises on every page so that it can create a sense of admiration for readers when opening each page. Furthermore, the research was carried out by (Pramesti, 2015) The use of pop up book media is seen as making it easier for students to obtain material during the learning process. Subsequent research was carried out by (Putri et al., 2019) shows that pop up book media can improve the ability to listen to the theme of loving plants and animals around grade III. Furthermore carried out by (Winarti \& Setiani, 2019) states that the use of pop up book media can improve the mathematics learning outcomes of grade $\mathrm{V}$ students. Other studies were conducted by (Dewanti et al., 2018) concluded that pop up media helps students understand the learning material so that it has an impact on student learning outcomes.

Their research results prove that using pop up book media can improve the quality of learning. Based on the explanation above, the TPS model and pop up media were chosen by the researcher as an effort to improve student learning outcomes. Previous research which also used the think pair share learning model was conducted by (Winantara, 2017) concluded that using the think pair share learning model can improve science learning outcomes in grade V. Furthermore, the research was carried out by (Citra Wibawa, 2018) states that applying the think pair share model can improve science learning outcomes in grade V. Subsequent research was carried out by (Dewi \& Dharsana, 2020) the use of think pair share technique can improve thematic learning outcomes in grade VA SD. Other research was conducted by (Pendidikan et al., 2017) with the think pair share learning model will have a positive effect on science learning outcomes of class V students. And the last research was conducted by (Sukreni et al., 2017) the application of the think pair share model can improve student learning outcomes and student interest in learning.

Based on the explanation above, it can be concluded that the think pair share learning model assisted by pop up media can improve student learning outcomes. In previous research, the think pair share learning model and pop up media were applied separately. However, this research will be made different from previous research. Researchers will try to collaborate the think pair share learning model with pop up media to be able to analyze improving learning outcomes in the realm of knowledge and skills.

\section{Method}

This research is a Classroom Action Research which refers to the model proposed by Kemmis and Mc Taggart. This design consists of 4 stages, namely planning (planning), action (acting), observation (observing), and reflection (reflecting). For more details, see Figure 1.

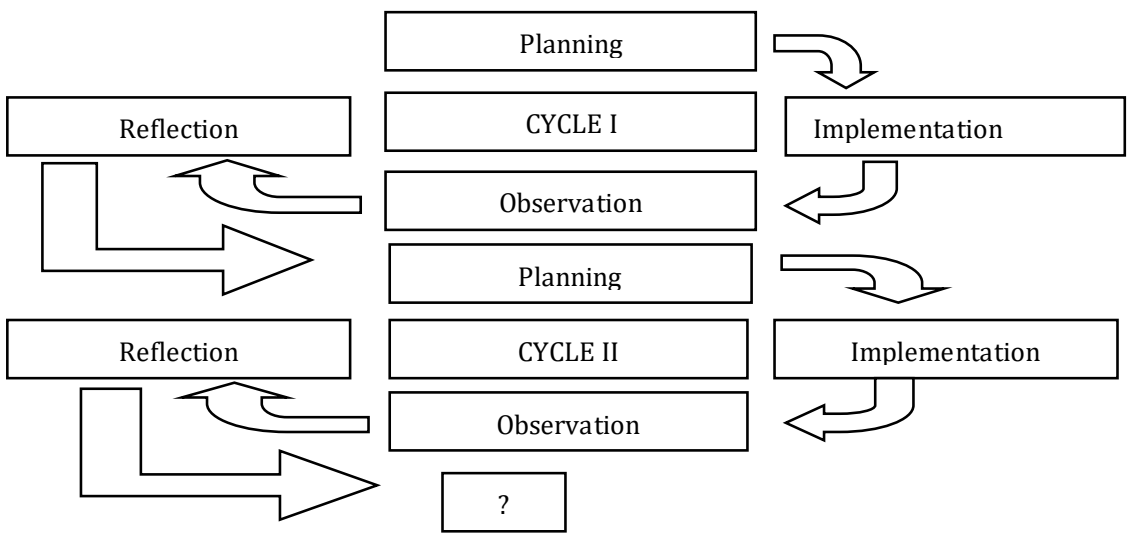

Figure 1. Classroom Action Research Cycle (Arikunto et al 2011: 16)

This research was conducted in 2 cycles, each cycle carried out 2 meetings. This research was conducted on fifth-grade students of SD 3 Bulungcangkring second semester of the 2019/2020 school year. The subjects in this study were 23 students of class V for the 2019/2020 school year, consisting of 13 students and 10 female students. SD 3 Bulungcangkring is located at Jl. Buyut Sipah Bulungcangkring RT 03 RW 09, Jekulo sub-district, Kudus Regency, Central Java province. 
Data collection techniques used in this study are tests, observation, interviews, and documentation. The data analysis method used in this research is quantitative data analysis and qualitative data analysis. Quantitative data analysis was used to calculate the test results of student learning in the domain of knowledge, amounting to 10 items. While the qualitative data analysis in the form of observations was carried out by researchers to observe the learning outcomes of skills during the learning process. Interviews in this study were used to obtain information about problems that exist in the learning process so that the data can be used as a basis for conducting research. This study uses documentation by producing documents in the form of writing and pictures related to the learning process.

Indicators of success in this study are 1) Student learning outcomes in the realm of knowledge on hot themes and their transfer can be said to increase if the value obtained is $\geq 70$ with $70 \%$ classical completeness. 2) Student learning outcomes in the domain of hot theme skills and their transfer can be said to increase if the value obtained is $\geq 70$ with $70 \%$ classical completeness.

\section{Result and Discussion}

This classroom action research lasted for 2 cycles, namely, cycle I and cycle II, each cycle consisting of 2 meetings. In cycle I, the first meeting of this research was conducted on January 8, 2020, and cycle I, the second meeting was held on January 9, 2020, while in cycle II the first meeting was held on January 22, 2020, and cycle II, the second meeting was held on January 23, 2020. At the end of each cycle, an evaluation test is conducted to measure the ability of student learning outcomes in the domain of knowledge on hot theme 6 and the displacement of fifth-grade students at SD 3 Bulungcangkring.

Based on the Semester Middle Deuteronomy data obtained by the researcher, in the Social Studies content there are $30 \%$ or 7 students who have achieved learning completeness and $70 \%$ or 16 students who have not achieved learning completeness while in the Indonesian language content there are $35 \%$ or 8 who have reached learning completeness and $65 \%$ or 15 students who have not achieved completeness in learning. If analyzed the learning outcomes of the fifth-grade students of SD 3 Bulungcangkring are included in the category of needing guidance. This requires action to improve student learning outcomes in the realm of knowledge.

The learning outcomes of the fifth-grade students of SD 3 Bulungcangkring by applying the think pair share learning model assisted by pop-up media were measured using an evaluation test in the form of a description of 10 items given to students at the end of the cycle I and cycle II. The subjects in the classroom action research conducted by the researcher were students of class V SD 3 Bulungcangkring with 23 students consisting of 13 students and 10 female students. The realm of knowledge consists of 6 aspects according to Lorin Anderson Krathwohl (Kosasih 2014) in the following order: (C1) remembering, (C2) understanding, (C3) applying, (C4) analyzing, (C5) evaluating, (C6) create.

Student learning outcomes increase from the beginning of the pre-cycle to cycle II if the quality of teachers when managing to learn is done well, causing student learning outcomes to increase. Student success in learning also depends on the material presentation model, if the presentation of material that does not make students feel bored, interesting, and easy to understand by students and of course affects student learning success and during the learning process the teacher delivers material by applying the think pair share theme The heat and the transfer assisted by pop up media have been done as much as possible, but there are still some students who are not enthusiastic about participating in learning, often play with their friends so that learning is not conducive. Due to problems in cycle I, the teacher made improvements in cycle II by guiding students who often play with their friends so that students are more serious in participating in learning and the class becomes conducive.

After the repairs were held in cycle II, there was an increase in cycle I to cycle II. The following is an increase in learning outcomes in the realm of knowledge that can be seen in table 1.

Table 1. Knowledge Domain Learning Outcomes

\begin{tabular}{|c|c|c|c|c|c|}
\hline \multicolumn{5}{|c|}{ Knowledge Domain Learning Outcomes } & \multirow{3}{*}{ Progress } \\
\hline & \multicolumn{2}{|c|}{ Cycle I } & \multicolumn{2}{|c|}{ Cycle II } & \\
\hline & IPS & B. I & IPS & B.I & \\
\hline $\begin{array}{c}\text { Average } \\
\text { value }\end{array}$ & 69 & 70 & 79 & 80 & Incronsin \\
\hline $\begin{array}{l}\text { Mastery } \\
\text { learning }\end{array}$ & $52 \%$ & $57 \%$ & $78 \%$ & $83 \%$ & increasing \\
\hline
\end{tabular}


Data from table 1. In the first cycle, the social studies content obtained an average value of 69 criteria for guidance (D) with 52\% learning completeness or 12 students who completed, while the Indonesian language content obtained an average score of 70 criteria sufficient (C) with completeness learn $57 \%$ or 13 students who complete and in cycle II have increased again so that the social studies content the classical average value becomes 79 criteria sufficient (C) with the completeness of learning $78 \%$ or 5 students who complete, while in Indonesian content the average score Classical average in cycle II obtained 80 good criteria (B) with $83 \%$ learning completeness or 4 students who completed. Thus, classroom action research by applying the think pair share learning model assisted by pop up media in grade V SD 3 Bulungcangkring is said to have been successful because it increases the learning outcomes of the knowledge desired by researchers, namely $\geq 70 \%$ with sufficient criteria (C).

Learning outcomes in the realm of skills according to the Education and Culture Ministry. 104/2014 describes the realm of skills there are two, namely the realm of abstract skills and the realm of concrete skills. The realm of abstract skills includes: 1) observing, 2) asking, 3) collecting, 4) trying, 5) reasoning, 6) communicating while the realm of concrete skills includes: 1) imitating, 2) doing, 3) describing, 4) assembling, 5) creating. For the realm of skills, the researcher takes one of the Minis, namely concrete skills (creating) this is to observe students' writing skills. The observation sheet of learning outcomes in the realm of skills consists of 4 observed aspects, namely (1) content comprehension, (2) organizational accuracy of text content, (3) diction accuracy, (4) spelling and writing procedures. In table 2. Learning Outcomes in the Skills Domain.

Table 2. Learning Outcomes in the Skills Domain.

\begin{tabular}{|c|c|c|c|c|c|}
\hline \multicolumn{5}{|c|}{ Learning Outcomes in the Skills Domain. } & \multirow{3}{*}{ Progress } \\
\hline & \multicolumn{2}{|c|}{ Cycle I } & \multicolumn{2}{|c|}{ Cycle II } & \\
\hline & Per. I & Per. II & Per. I & Per. II & \\
\hline Total Value & 1510 & 1623 & 1736 & 1840 & \multirow{4}{*}{ Increasing } \\
\hline Average & 66 & 71 & 75 & 80 & \\
\hline $\begin{array}{l}\text { Average } \\
\text { Cycle }\end{array}$ & \multicolumn{2}{|c|}{69} & & & \\
\hline Category & \multicolumn{2}{|c|}{ Need Supervision } & \multicolumn{2}{|c|}{ Pretty Good } & \\
\hline
\end{tabular}

Based on the observation of learning outcomes in the realm of skills in the first cycle of the meeting I obtained a value of 1510 with an average of 66 criteria needed guidance, and in the first cycle of meeting II obtained a value of 1623 with an average of 71 criteria sufficient. So that the classical average in the first cycle obtained 69 criteria for guidance. In cycle, I have not reached the indicators of success, because during the learning process some students could not understand the contents of an explanatory text so that students still had difficulty in making a summary, therefore students' writing skills were low, with teacher guidance and guidance at each meeting. students can understand the content of a text and can retell the content of a text in writing. So, in the second cycle, the first meeting experienced an increase in obtaining a value of 1736 with an average of 75 with sufficient criteria, while in the second cycle of the second meeting, it had a value of 1840 with an average of 80 sufficient criteria. So that the classical average in the second cycle increased to get 78 sufficient criteria. Thus, the classroom action research by applying the think pair share learning model assisted by pop up media in grade V SD 3 Bulungcangkring is said to have been successful because it increases the learning outcomes of the skills desired by the researcher, namely $\geq 70$ with sufficient criteria.

Apart from being based on the test results, several things show that the application of the think pair share learning model assisted by the media pop up book improves student learning outcomes, some of these things are.

First, the syntax of the think pair share learning model emphasizes students on active thinking activities to gain knowledge. In the preliminary stage, students are given a stimulus in the form of problems that have been prepared through the pop-up book media. Furthermore, students are directed at the thinking stage, at this stage students have started to think to understand the problem and the solutions given, this activity will increase students' thinking abilities. After that, the next stage students convey the results of these thoughts to group friends, in the group all ideas and discussion from students will be responded to by group members. At this stage, there is a process of exchanging ideas so that students 'understanding is more complete, besides that the students' ability to communicate will be more honed. Furthermore, when the group discussion is over students will present the results of the discussion in groups in front of the class. Students who listen will respond and give opinions, while group members can help friends who are presenting. The final stage is giving rewards and correcting wrong concepts, at 
this stage students will be more enthusiastic about learning to get rewards. This statement is in accordance with the opinion of (Huda, 2015) which states that the TPS learning model gives students time to think about answers to the questions or problems being discussed, then students solve these problems with their respective abilities. In addition to expert opinion, these results are supported by several studies, this research is a research conducted by (Winantara, 2017), he found that the application of the TPS learning model made students active in the learning process and students became more understanding because of the process of exchanging ideas with friends. Furthermore, research conducted by (Shoimin, 2017) stated that the think pair share model is a cooperative learning model that gives students time to think and respond and help each other. Research conducted by (Puspitasari, 2016) found that student learning outcomes increased after being given learning using the TPS learning model, in learning students were used to working in groups and dared to express opinions. Further research by (Kurniasari \& Setyaningtyas, 2017) shows that the application of the think pair share model can improve social studies learning outcomes, this increase in learning outcomes is obtained because students are accustomed to brainstorming and listening well. Furthermore carried out by (Rismawati \& Ganing, 2019) With the application of the think pair share model it can improve science learning outcomes in grade $V$, the increase in learning outcomes occurs because students who feel unsatisfied will find it helpful to presentations from friends. Subsequent research was carried out by (Afiyahni et al., 2019) stated that the application of the think pair share cooperative learning model can affect student learning outcomes. Other research was also carried out by (Tambusai, 2018) who said that the think pair share learning model can improve student learning outcomes. Last carried out by (Aryadiputra et al., 2020) concluded that the think pair share learning model can affect the learning outcomes of class V students.

Second, students' skills increase due to TPS learning model activities that focus student activities on thinking activities which include observing, asking, collecting, reasoning, doing. In observing and reasoning activities, students do activities to think about problems given by the teacher. Then students continue to do activities to collect ideas from group members after collecting ideas. Students do reasoning activities again to get complete answers and understanding. In the end, the students presented the results of the discussion, at the discussion stage students could ask questions or responses. This statement is in accordance with the opinion of experts, namely (Trianto, 2014), the TPS learning model is a learning model that affects student interaction patterns, the student interaction pattern that is influenced is that students carry out discussion activities while doing repeated thinking activities. Furthermore, (Huda, 2015) conveyed that the TPS learning model gave students time to think about answers to the questions or problems being discussed, then students solve these problems with their respective abilities then explain the results obtained in front of the class. This statement is supported by several studies, namely research conducted by (Pramawati, 2016), she found that students' creative thinking skills increased after being given learning using the TPS learning model, this happened because students were allow ed to think and study problems. Furthermore, research by (Febriany, 2018) found that students who took the TPS learning mode would be better trained to carry out scientific activities such as observing, observing, and asking questions. other research that is in line with this research was conducted by (Faridha et al., 2015) which shows that applying the think pair share model can improve student learning outcomes in the psychomotor domain, this is because in learning students are used to doing skills such as speaking, questioning and reasoning. Each of these skills is honed through student activities in groups. Furthermore, carried out by. Subsequent research was carried out by (Lakilaf \& Suarjana, 2017) said that using the think pair share learning model can improve students' writing skills, students' writing skills increase because students are accustomed to doing activities related to writing, for example when learning takes place students first write down questions related to their friends' presentations.

Third, pop up book media is proven to improve student learning outcomes. This is because the pop-up book media attracts students' attention, students feel interested in learning because the pop-up book contains interesting images and students can interact with the learning media directly. This media can also improve students' memory about a concept, this is because the media can be 3-dimensional and similar to the original. This statement is supported by an opinion according to (Dzuanda, 2011), which states that the Pop-Up book is a book that has a moving part or has 3-dimensional elements and provides a more interesting visualization of the story, starting from the display of images that can move when the page is opened. (Muktiono, 2003), Pop Up book is a book that has an image display that can be established and forms beautiful objects and can move or give amazing effects. In addition to expert opinion, several studies support these results, this research is research conducted by (Setyowati, 2017) concluded with that the use of pop up book media can improve the writing skills of fourth-grade students, this is because the pop-up book media is interesting and the pictures make students remember the material more. This makes students remember the material they are going to write better. Furthermore, ( Khoiriyah's, 2018) research found that pop up book media can increase student activity in learning and improve student 
learning outcomes, this is indicated by the enthusiasm of students in using learning media, which initially passive students become more active and courageous. The next research is (Dewanti's, 2018) research in this study found that pop up media makes it easier for students to understand the material so that student learning outcomes can improve. The next research was carried out by (Mustofa, 2018), he found that grade 3 students who were given learning with pop up book media made it easier for students to understand abstract concepts. This is because the pop-up book media can be used directly by students, besides that pop-up book media can also be made in a 3-dimensional form and become more real.

\section{Conclusions and suggestions}

Based on the results of the research and the results of data analysis that has been carried out, it can be concluded that by using the think pair share learning model assisted by pop-up media there is an increase in learning outcomes of knowledge and skills on the theme of heat and its displacement. From this conclusion, the researchers gave some suggestions aimed at the school to make the think pair share learning model and pop up media as a reference to be applied when integrated thematic learning, schools should provide motivation to teachers to further develop their skills in implementing learning and providing adequate facilities and infrastructure so that teachers are more innovative during learning. Teachers are advised to improve student learning outcomes and also to motivate students to participate actively in the learning process and be skilled in class management.

\section{References}

Aeni, N. (2018). Pendidikan Nilai Nasionalisme Dengan Media Pop Up Book Untuk Meningkatkan Berpikir Kritis Siswa Kelas V Sekolah Dasar. Jurnal Review Pendidikan Dasar : Jurnal Kajian Pendidikan Dan Hasil Penelitian, 4(3), 752. https://doi.org/10.26740/jrpd.v4n3.p752-762

Afiyahni, F. D., Huda, C., \& Listyarini, I. (2019). Keefektifan Model Pembelajaran Kooperatif Think Pair and Share Berbantu Media Diorama Terhadap Hasil Belajar Tematik Integratif. Mimbar PGSD, 7, 230236. http://dx.doi.org/10.23887/jjpgsd.v7i3.19394

Ardianti, Dwi Sekar., Ulya, Himmatul., Ismaya, Erik Aditia. (2018). Pakem dalam Kurikulum 2013. Kudus: Badan Penerbit Universitas Muria Kudus.

Arikunto, Suharsimi., Suhardjono., Supardi. (2011). Penelitian Tindakan Kelas. Jakarta: PT Bumi Aksara.

Aryadiputra, I. G. P., Wayan, A. I., \& Yuda, I. (2020). Think Pair Share Meningkatkan Hasil Belajar IPS. 8(2), 274-283. http://dx.doi.org/10.23887/jjpgsd.v8i2.24694

Citra Wibawa, I. M. (2018). Pengaruh Model Pembelajaran Think Pair Share Berbantuan Power Point Terhadap Hasil Belajar Ipa. Jurnal Imiah Pendidikan Dan Pembelajaran, 2(1), 38-46. https://doi.org/10.23887/jipp.v2i1.13975

Dewanti, H., Toenlioe, A. J. E., \& Soepriyanto, Y. (2018). Pengembangan media Pop-Up Book untuk Pembelajaran Lingkungan Tempat Tinggalku Kelas IV SDN 1 Pakuaden Kabupaten Ponorogo. Jurnal $\begin{array}{llll}\text { Kajian Teknologi Pendidikan, 221-228. } & \text { 1(3), }\end{array}$ http://journal2.um.ac.id/index.php/jktp/article/viewFile/4551/3408

Dewi, K. R., \& Dharsana, I. K. (2020). Penggunaan Teknik Think Pair Share dan Teknik Index Card Match Dalam Lesson Study Mampu Meningkatkan Hasil Belajar Siswa. Jurnal Pedagogi Dan Pembelajaran, 3(2), 248. https://doi.org/10.23887/jp2.v3i2.26554

Dzuanda. 2011. Design Popup Child Book Puppet Figures Series Gatotkaca. JurnalLibrary ITS Undergraduate, (Online), (http; //library,its.undergraduate,ac.id, diakses pada 10 Oktober 2015).

Eri Karisma, I. K., Margunayasa, I. G., \& Prasasti, P. A. T. (2020). Pengembangan Media Pop-Up Book pada Topik Perkembangbiakan Tumbuhan dan Hewan Kelas VI Sekolah Dasar. Jurnal Ilmiah Sekolah Dasar, 4(2), 121. https://doi.org/10.23887/jisd.v4i2.24458

Faridha, A., Abbas, N., \& April, D. (2015). PENERAPAN MODEL THINK PAIR SHARE BERBANTUAN PUZZLE UNTUK Standar Kompetensi IPS adalah untuk mendidik dan memberi untuk mengembangkan diri sesuai dengan bakat, Kompetensi Dasar Tingkat SD / MI dalam Peraturan Menteri Pendidikan $\begin{array}{llllll}\text { Nasional } & \text { Nomor } & 22 & \text { Tahun } & 20 . & 4(5) .\end{array}$ https://journal.unnes.ac.id/sju/index.php/jlj/article/view/7460 
Huda, Miftahul.2015. Model-Model Pengajaran dan Pembelajaran. Yogyakarta.Pustaka Belajar,hal.197-199

Jasdilla, L., Kuswendi, U., \& Ramdhani, S. (2017). Hasil Belajar Dan Pembelajaran Kooperatif Tipe Think Pair Share (Tps). JPI (Jurnal Pendidikan Indonesia), 6(1), 96-105. https://doi.org/10.23887/jpiundiksha.v6i1.9253 http://dx.doi.org/10.23887/jpi-undiksha.v6i1.9253

Kosasih. (2014). Strategi Belajar dan Pembelajaran Implementasi Kurikulum 2013. Bandung: Yrama Widya.

Kurniasari, E. F., \& Setyaningtyas, E. W. (2017). Peningkatan Hasil Belajar IPS Melalui Penerapan Model Pembelajaran Kooperatif Tipe Think Pair and Share (TPS) dengan Teknik Gallery Walk. Journal of Education Research and Evaluation, 1(2), 120. https://doi.org/10.23887/jere.v1i2.10074

Lakilaf, N. S., \& Suarjana, I. M. (2017). Penerapan Model Think-Pair-Share Untuk Meningkatkan Keterampilan Menulis Kelas Ii Sdn 3 Banjar Jawa. Jurnal Ilmiah Sekolah Dasar, 1(4), 284. https://doi.org/10.23887/jisd.v1i4.12295

Litna, K. O., \& Seli, M. S. (2019). Penerapan Model Pembelajaran Kooperatif Tipe Think-Pair-Share ( TPS ) untuk Meningkatkan Aktivitas dan Prestasi Belajar Matematika. 3(4), 504-510.

Masturah, E. D., Mahadewi, L. P. P., \& Simamora, A. H. (2018). Pengembangan Media Pembelajaran Pop-Up Book pada Mata Pelajaran IPA Kelas III Sekolah Dasar. Jurnal EDUTECH Universitas Pendidikan Ganesha, 6(2), 212-221. https://doi.org/10.21067/jbpd.v2i2.2495

Muktiono, Joko. 2003. Menumbuhkan Minat Baca Pada Anak. Jakarta: PT. ElexMedia Komputindo.

Ni'mah, N. (2014). Efektivitas penggunaan media Pop Up dalam pengajaran keterampilan berbicara bahasa Perancis siswa kelas IX SMA Negeri 1 Mertoyudan Magelang. FBS-UNY. https://eprints.uny.ac.id/13365/

Peraturan Menteri Pendidikan dan Kebudayaan Republik Indonesia No 104 Tahun 2014 tentang Penilaian Hasil Belajar Oleh Pendidik Pada Pendidikan Dasar dan Pendidikan Menengah. (2014). Jakarta: PT Armas Duta Jaya.

Pramesti, J. (2015). Pengembangan Media Pop-Up Book Tema Peristiwa. Jurnal Pendidikan Guru Dan Sekolah http://journal.student.uny.ac.id/ojs/ojs/index.php/pgsd/article/view/1194/1066

Dasar,IV.

Putri, Q. K., Pratjojo, P., \& Wijayanti, A. (2019). Pengembangan Media Buku Pop-Up untuk Meningkatkan Kemampuan Menyimak Tema Menyayangi Tumbuhan dan Hewan di Sekitar. Jurnal Pedagogi Dan Pembelajaran, 2(2), 169. https://doi.org/10.23887/jp2.v2i2.17905

Putri Suyanti, Nurdinah Hanifah, D. T. S. (2017). Jurnal pena ilmiah: vol 2, No 1 (2017). Jurnal Pena Ilmiah, 2(1), 2051-2060. ejournal.upi.edu/index.php/penailmiah/article/download/3566/pdf\%0A\%0A

Rismawati, N. W. R., \& Ganing, N. N. (2019). Pengaruh Model Pembelajaran Mind Mapping Berbantuan Media Audiovisual Terhadap Kompetensi Pengetahuan Ipa. Journal for Lesson and Learning Studies, 2(3), 462-470. https://doi.org/10.23887/jlls.v2i3.19509

S.E., M., \& Dra. Ni Wayan Suniasih, S. (2018). Pengaruh Model Pembelajaran Think Pair Share Berbasis Penilaian Portofolio Terhadap Kompetensi Pengetahuan Ipa Siswa Kelas Iv Sd Negeri Gugus Kapten Kompyang Sujana Denpasar Barat Tahun 2017/2018. MIMBAR PGSD Undiksha, 6(3), 161-168. https://doi.org/10.23887/jjpgsd.v6i3.15772

Sentarik, K., \& Kusmariyatni, N. (2020). Media Pop-Up Book pada Topik Sistem Tata Surya Kelas VI Sekolah Dasar. Jurnal Ilmiah Sekolah Dasar, 4(2), 197. https://doi.org/10.23887/jisd.v4i2.25135

Setyowati, D. (2017). Penggunaan Media “Pop Up Book” Untuk Meningkatkan Keterampilan Menulis Deskripsi Siswa Kelas Iv Sdn Cerme Lor - Gresik. Jurnal Penelitian Pendidikan Guru Sekolah Dasar, 5(3), 254587. https://media.neliti.com/media/publications/254587-none-dfad396d.docx.

Shoiman, Aris. (2017). 68 Model Pembalajaran Inovatif dalam Kurikulum 2013. Yogyakarta: Ar Ruzz Media.

Sni, M. E., \& Hero, H. (2018). Jurnal Riset Pendidikan Dasar. Riset Pendidikan Dasar, 1(April), 25-33.

Sukreni, N. K., Agung, A. A. G., Citra, I. M., Guru, P., Dasar, S., \& Pendidikan, F. I. (2017). Pengaruh Model Pembelajaran Tps Dan Minat Siswa Kelas V. 1-9. http://dx.doi.org/10.23887/jjpgsd.v5i2.11035

Syarifah, H., Indriwati, S. E., \& Corebima, A. D. (2016). Pengaruh strategi pembelajaran reading questioning and answering (RQA) dipadu think pair share (TPS) terhadap keterampilan metakognitif siswa laki- 
laki dan perempuan SMAN di Kota Malang.Jurnal Pendidikan: Teori, Penelitian, dan Pengembangan, 1(5), 801-805. http://dx.doi.org/10.17977/jp.v1i5.6259

Tambusai, T. (2018). Improving learning outcomes by using Think Pair Share ( TPS ) Cooperative Learning model at Primary School students. Jurnal Pendidikan Indonesia, 7(2), 77-85. https://ejournal.undiksha.ac.id/index.php/JPI/article/view/10469/9883

Tanjung, K. S., \& Wardani, N. S. (2020). Efektivitas Pembelajaran Tematik PPBL-TPS Terhadap Motivasi Belajar Peserta Didik. 8, 123-132. http://dx.doi.org/10.23887/jjpgsd.v8i1.24585

Undang-undang Republik Indonesia No 20 Tahun 2003 tentang Sistem Pendidikan Nasional. (2004). Jakarta: PT Armas Duta Jaya.

Ustatik. (2016). Peningkatan Hasil Belajar Matematika Pokok Bahasan Operasi Perkalian dan Pembagian dengan Model Kooperatif Tipe TPS. Jurnal UNEJ, Volume 5 Nomor 4. https://jurnal.unej.ac.id/

Winantara, I. W. D. (2017). Penerapan Model Pembelajaran Tps Untuk Meningkatkan Hasil Belajar Ipa Siswa Kelas V Sd No 1 Mengwitani. Journal of Education Action Research, 1(2), 148. https://doi.org/10.23887/jear.v1i2.12047

Winarti, D., \& Setiani, R. (2019). Efektivitas Media Pop Up Book Pada Pembelajaran Cooperatif Tipe Make a Match Terhadap Hasil Belajar Matematika. JRPD (Jurnal Riset Pendidikan Dasar), 2(2), 136-142. https://doi.org/10.26618/jrpd.v2i2.2480

Yustitia, V., Rusminati, S. H., \& Sulistyawati, I. (2018). Penerapan model think pair share dengan pendekatan saintifik melalui lesson study pada mata kuliah evaluasi pembelajaran SD. Premiere Educandum: Jurnal Pendidikan Dasar Dan Pembelajaran, 8(1), 88. https://doi.org/10.25273/pe.v8i1.2621 